\title{
Heuristic evaluation on mobile halal detection application
}

\author{
Ahmad Hasan Ridwan', Irfan Safrudin', Muhammad Ali Ramdhani ${ }^{3}$, Diena Rauda Ramdania \\ ${ }^{1}$ Department of Islamin Law, UIN Sunan Gunung Djati Bandung, Indonesia \\ ${ }^{2}$ Department of Islamic Studies, Universitas Islam Bandung, Indonesia \\ ${ }^{3,4}$ Department of Informatics, UIN Sunan Gunung Djati Bandung, Indonesia
}

\begin{tabular}{l} 
Article Info \\
\hline Article history: \\
Received Jan 10, 2020 \\
Revised Feb 13, 2020 \\
Accepted Mar 9, 2020 \\
\hline Keywords: \\
Halal \\
Heuristic evaluation \\
Human-computer interaction \\
Mobile application \\
MUI
\end{tabular}

\begin{abstract}
As a country with the largest Muslim population in the world, the halal status of a food and beverage product is essential for the people of Indonesia. An application was created by the government to answer these concerns with the name "Halal MUI." Unfortunately, this application has not been able to meet the needs of users to get a rating of 3.5 out of 920 users. This study aims to provide an evaluation of the Halal MUI application by using A heuristic evaluation approach. As many as three experts did a personal heuristic evaluation, then summarized it in a group discussion forum. The results showed that the application of Halal MUI, in general, has been able to check the halal product. However, some features still have a high severity rating. This paper presents several suggested improvements to improve system usability in Halal MUI applications.
\end{abstract}

Copyright $@ 2020$ Institute of Advanced Engineering and Science. All rights reserved.

\section{Corresponding Author:}

Ahmad Hasan Ridwan,

Department of Islamic Law,

UIN Sunan Gunung Djati Bandung,

A.H Nasution Street No 105, Cipadung, Bandung 40614, Indonesia.

Email: ahmadhasanridwan@uinsgd.ac.id

\section{INTRODUCTION}

In 2019, the number of the Muslim population in Indonesia reached 256.8 million [1]. This figure is up by 47,7 million from the previous year. A large number of the community makes Indonesia a potential market for product marketing. However, as the country with the largest Muslim population in the world [2], Muslims need to pay attention to the food and drinks consumed. This awareness is in line with the command of Allah, which commands Muslims to eat halal food and toyyib. The meaning of Halalan thayyiban is related to the behavior and personality of a Muslim about a good and clean way of life [3]. Such an attitude is similar to food and drinks that must be halal and clean [4]. Al-Quran contains the word halal (halalun) once, namely: Q.S Al-Nahl: 116, halal words once, namely: Q.S. Yunus: 59; while the halal words with thayyiban four times Q.S. Al-Baqarah: 168; Al-Maidah: 88; Al-Anfal: 69; An-Nahl: 114.

As the government also supports protection for $87 \%$ of Muslim consumer communities. The importance of consuming halal products is even mentioned in food laws, consumer protection laws, and government regulations governing technical regulations [5]. Through the Majelis Ulama Indonesia, the government also provides guarantees in the form of halal labels for products that have registered and passed the MUI halal test. Products that have a halal certificate and halal label are products that comply with Islamic teachings. Products that are justified for consumption according to this Shariah are quality products, do not endanger health, and do not contain elements that are prohibited in Islam, both in material content and manner of manufacture [6]. As a means to facilitate the public in examining halal products, the Indonesian Food and Drug Research Institute (LPPOM MUI) [7] even make Halal applications that can be downloaded and installed directly on the user's mobile phone. Until now, the Halal MUI application has been downloaded by 959 users [8]. 
Various features are offered in the Halal MUI application, including a search for halal products, barcode scans, halal certifications, halal questions, halal restaurants, and LPPOM MUI call centers. Through this application, the method of checking halal products can be quickly done by scanning the product barcode. The user selects the barcode scan menu, then points the smartphone camera at the product barcode. The application will later display information in the form of product name, manufacturer of product maker, the certificate number, and valid date. Unfortunately, the available apps are still not enough to meet the needs of users, thus obtaining a rating of 3.8 from a maximum of 5 .

This study aims to evaluate the application of Halal MUI with the Heuristic Evaluation method. Heuristic Evaluation is a review or inspection of a product by an expert [9]. The purpose of heuristic evaluation is to improve the design in the form of existing designs or software effectively [10]. This method has been used in several previous studies and is proven to be able to provide suggestions for improvement. The researches that have been made previously include: assessing the design of PT POS Indonesia's online payment point system [11], the use of a mobile sports center application [12], the application interface of an Indohome pay-TV service [13], controlling the activities of students [14], website [15, 16], virtual reality [17], information system [18], and so on. Heuristic Evaluation in the Halal MUI application aims to provide suggestions for improvement in terms of design. The purpose of this research is expecting to be an input for makers of Halal MUI applications to achieve high user experience.

\section{HEURISTIC EVALUATION}

\subsection{Heuristic evaluation}

Nielsen and Molich proposed heuristic evaluation. This method provides a structured direction regarding usability assessment. The heuristic evaluation uses guidelines, general principles, rules, and experience that can help a decision or critique of a predetermined decision [19-24]. The laws in this method describe in Table 1.

Table 1. Heuristic evaluation method

\begin{tabular}{|c|c|c|}
\hline No & Heuristic Aspect & Meaning \\
\hline 1 & $\begin{array}{l}\text { Visibility of system status } \\
\text { (feedback) }\end{array}$ & $\begin{array}{l}\text { The system always informs the user what is happening, through a good message and } \\
\text { the right time. }\end{array}$ \\
\hline 2 & $\begin{array}{l}\text { Match between the system and the } \\
\text { real world }\end{array}$ & The language used in the apps must be following the user's language. \\
\hline 3 & Use Control and Freedom & $\begin{array}{l}\text { The system must have the ability to undo and red, so the users are free to choose the } \\
\text { work and make decisions. }\end{array}$ \\
\hline 4 & Consistency and Standards & $\begin{array}{l}\text { The system has the same standards in the choice of words, sentences, situations, and } \\
\text { actions so that users do not feel confused. }\end{array}$ \\
\hline 5 & Error Prevention & The system has error prevention. \\
\hline 6 & Recognition Rather than Recall & $\begin{array}{l}\text { Minimize user memory usage by making the interface easy to remember. The } \\
\text { excellent system presents visible or easily retrievable instructions whenever needed. }\end{array}$ \\
\hline 7 & Flexibility and Efficient of Use & $\begin{array}{l}\text { The system can accommodate users who are experts and users who are still } \\
\text { beginners. Allow users to tailor frequent actions. }\end{array}$ \\
\hline 8 & Esthetic and Minimalist Design & $\begin{array}{l}\text { The system produces relevant information because irrelevant information reduces } \\
\text { the visibility and usability of the system. }\end{array}$ \\
\hline 9 & $\begin{array}{l}\text { Help users recognize, dialogue, and } \\
\text { recovers from errors. }\end{array}$ & $\begin{array}{l}\text { The system must have objects, actions, and choices that are visible and easily } \\
\text { accessible, so users do not have to memorize information from one page to another. }\end{array}$ \\
\hline 10 & Help and Documentation & $\begin{array}{l}\text { the system must have relevant documentation and excellent support features so that } \\
\text { users can learn everything related to the system. }\end{array}$ \\
\hline
\end{tabular}

Heuristic evaluation is carried out by 3-5 evaluators. Based on the results of research conducted by Nielsen, one evaluator was only able to discover $35 \%$ of usability problems [25]. Each evaluator individually reviews the product at least twice, first to be familiar with the product, the second time to investigate The product. The results of each individual are then collected to be arranged in a meeting [9].

The assessment of existing rules is done by giving severity rating scores to each criterion. The severity is arranged on a scale as follows [22]:

$0=$ There are no usability errors,

$1=$ Cosmetic problem: It does not need to be fixed unless there is additional time in the project.

2 = Minor usability problem: The repair priority is low.

3 = Major usability problem: Important to be fixed. Must be given high priority.

4 = Usability Catastrophe: imperative to fix this before the product can be released. 


\subsection{Heuristic evaluation for mobile devices}

Ten of Nielsen's heuristic evaluation rules should ideally be applied to the website. For this reason, Enrico et al., a group of researchers from Switzerland, made adjustments to Nielsen's rules to be used to Mobile Computing [26]. Some of the adjusted rules are arranged, as described in Table 2.

Table 2. Heuristic evaluation for mobile device [18]

\begin{tabular}{|c|c|c|}
\hline No & Heuristic Aspect & Meaning \\
\hline 1 & $\begin{array}{l}\text { Visibility of the system status and loss } \\
\text { or findability of the mobile device. }\end{array}$ & $\begin{array}{l}\text { The system must always keep users informed of what is happening through } \\
\text { mobile devices. The system must also be able to prioritize messages about } \\
\text { critical and contextual information such as network status, battery status, } \\
\text { hours, and so on. }\end{array}$ \\
\hline 2 & $\begin{array}{l}\text { Match between the system and the } \\
\text { real world }\end{array}$ & $\begin{array}{l}\text { The information displayed by the system should be displayed naturally and } \\
\text { logically, making it easier for users to interpret the data correctly. If possible, } \\
\text { the knowledge presented by the system is adjusted to the user's environment. }\end{array}$ \\
\hline 3 & Consistency and mapping & $\begin{array}{l}\text { The functions and interactions that the system presents must be consistent } \\
\text { with the context. }\end{array}$ \\
\hline 4 & $\begin{array}{l}\text { Excellent ergonomics and minimalist } \\
\text { design }\end{array}$ & $\begin{array}{l}\text { The system must pay attention to the ergonomic side. Dialogue must not } \\
\text { contain information that is irrelevant or rarely needed. }\end{array}$ \\
\hline 5 & $\begin{array}{l}\text { Ease of input, screen readability, and } \\
\text { glanceability }\end{array}$ & $\begin{array}{l}\text { The system must provide convenience for users when entering data. If } \\
\text { possible, reduce or avoid leading users to use both hands. Screen content must } \\
\text { be easy to read and navigate in different light conditions. }\end{array}$ \\
\hline 6 & $\begin{array}{l}\text { Flexibility, the efficiency of use, and } \\
\text { personalization }\end{array}$ & $\begin{array}{l}\text { The system can accommodate users who are experts and users who are still } \\
\text { beginners. Allow users to tailor frequent actions. }\end{array}$ \\
\hline 7 & Aesthetic, privacy, and social & $\begin{array}{l}\text { Pay attention to the artistic and emotional aspects of the mobile device and the } \\
\text { system used in the user account. Ensure that user data is safe and privacy } \\
\text { protected. The system must also be comfortable to use. }\end{array}$ \\
\hline 8 & Realistic error management & $\begin{array}{l}\text { When an error occurs, help the user to diagnose or return to its original state. } \\
\text { The error message displayed must be clear and precise, also suggesting a } \\
\text { solution. This thing makes the user calm even when making mistakes. }\end{array}$ \\
\hline
\end{tabular}

\section{RESEARCH METHOD}

The research team evaluated the website from application users who provided reviews on Google Play and the Apple Store. At the initial meeting, the team reviewed the entire structure and contents of The application. At this stage, a research scenario was designed, namely how to scan barcodes of food and beverage products from home and abroad. This application was evaluated based on 10 Jakob Nielsen heuristic criteria, which have been adapted for mobile applications such as research by Enrico et.al. The team consists of 3 expert judgments [25]. At the first meeting, the team completed an individual heuristic evaluation. Then, in a follow-up meeting in the group discussion forum, the organization compiles individual evaluations into one report.

\section{RESULT AND ANALYSIS}

\subsection{Visibility of system status and findability of the mobile device}

The system interface should not put the user in a problematic condition. Feedback should be given to users to provide certainty. The evaluator found a confusing interface when choosing the Halal Certification menu. On this menu, there are two menus, namely Halal Certification and Halal Registration. When the Halal Registration menu is clicked, there is a "Register" button that directs to the e-lppommui.org/new web link. In Figure 1(a), a web page is visible after the "REGISTER" button is touched. On this web page, the page looks blank. There is no information or instructions on what users must do to register the product Figure 1(b). 


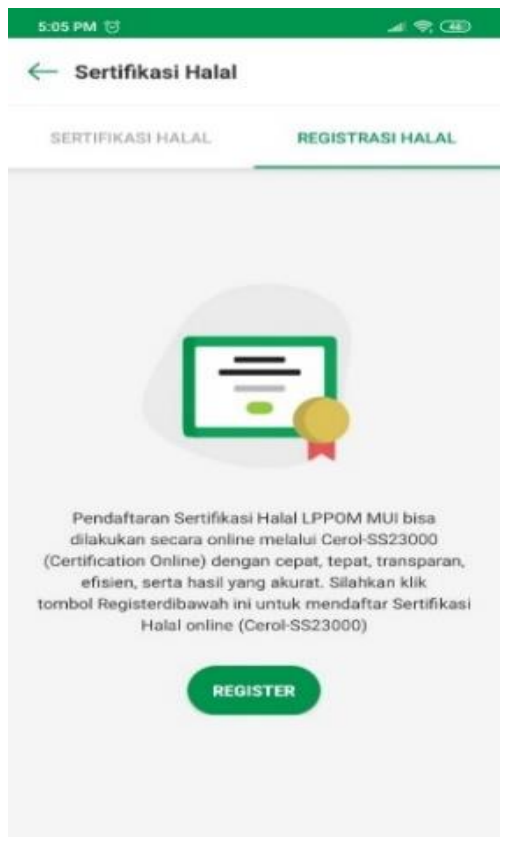

(a)

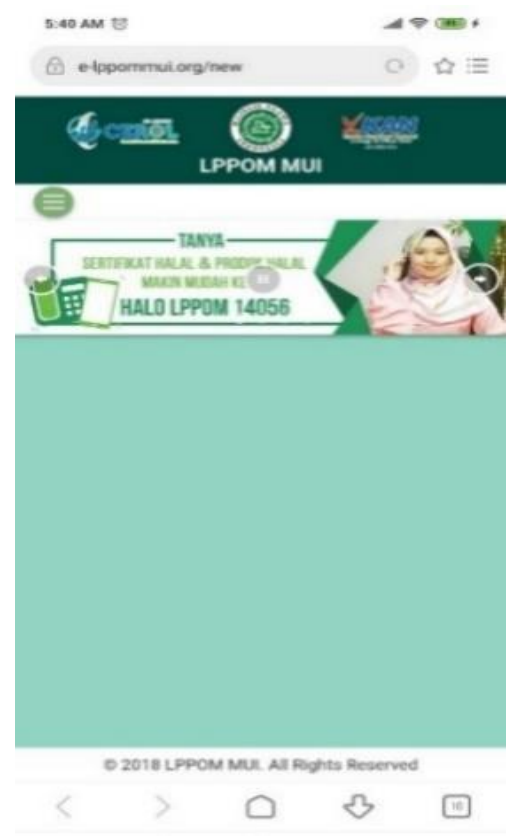

(b)

Figure 1. (a) Halal certification menu, (b) The display after the Register button is selected

\subsection{Match between the system and the real world}

The similarity of the system interface with the real world can be seen from the beauty of the designer in creating icons on the menu in the application. For example, to find halal products, the symbol used is a magnifying glass. Other icons used are barcode images on the barcode scan menu, food hoods on the Halal Resto menu, telephones on the Call Center menu, and so on. Overall the system interface is following the real world, so it has been very easy for users. In this case, the system is under the criteria.

\subsection{Consistency and mapping}

Evaluators assess the language used in the system is not consistent. This application has a menu in Bahasa, but the naming of buttons uses Indonesian and English, as illustrated in Figure 2.

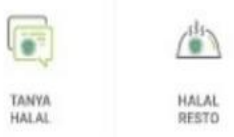

(a)

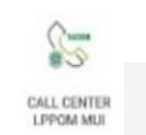

KIIIM

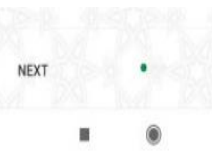

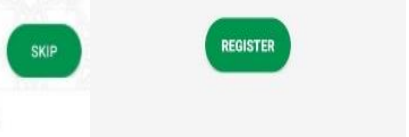

(b)

Figure 2. (a) menu button in Bahasa, (b) The menu button in the English language

\subsection{Good ergonomics and minimalist design}

The Halal MUI application uses a light gray base color with an icon color and a green button similar to the MUI halal logo color. The application interface design is relatively simple and does not make the eyes tired. The entire menu can also function properly. The minimalist design does not fill the user's memory to remember the application.

\subsection{Ease of input, screen readability, and glaceability}

Users can input manually on the product search menu and restaurant. When inputting numbers or restaurant names, the interface that is displayed is quite simple. Users can also input the search terms using only one hand. 


\subsection{Flexibility, the efficiency of use, and personalization}

All three evaluators assess the system's rigidity when scanning a product. When the product being scanned is not in the database, the system immediately displays the information "Product not registered" (Figure 3(b)). This problem is among the most protested by users because the scanned product has the MUI halal $\log 0$.

The system considers having rigidity because it does not offer any solution if the product is not registered or not yet in the database. Preferably, the system can provide solutions for example by giving The suggestion "You can search for products manually in the product search menu." Another limitation found by evaluators is when scanning packaging with protruding surfaces, such as beverage bottle packaging. The system failed to scan the barcode several times.

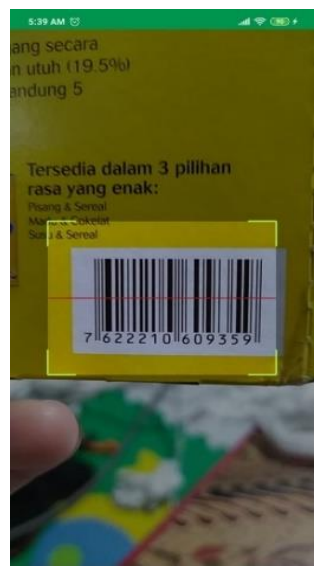

(a)

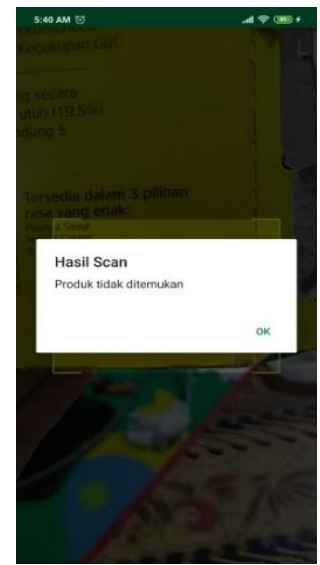

(b)

Figure 3. (a) Scan product barcode, (b) Product search results not listed in the database

\subsection{Aesthetic, privacy, and social}

A dialog must not contain irrelevant or irrelevant content, or information is required. Each component must provide meaning and function under the requirements of the application. The MUI application already meets these criteria.

The evaluator tried asking about the halal product on the "Ask Halal" menu (Figure 4(a)). The response given by the system is sent via email and is reasonably fast (a matter of hours), as shown in Figure 4(b). In privacy, the system has protected user privacy. The system also provides a solution for users to search the website by attaching the link via email. Unfortunately, the link is not "Not found" when clicked, as illustrated in Figure 4(c).

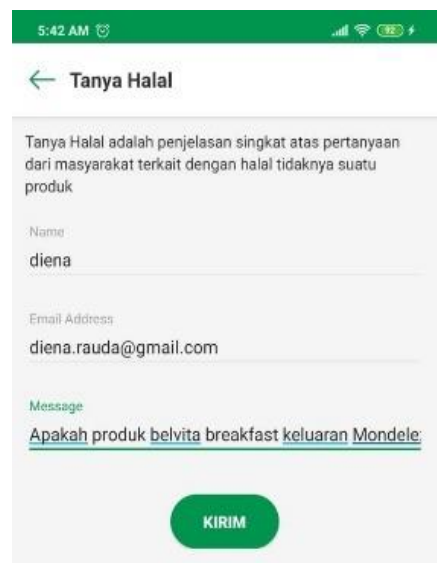

(a)

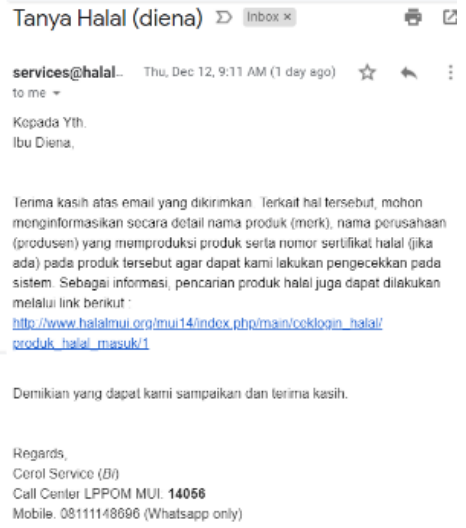

(b)

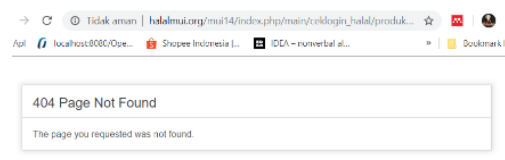

(c)

Figure 4. (a) the user asks through the "Ask Halal" menu, (b) the response was given by the system through email, (c) Display the link contained in the email 


\subsection{Realistic error management}

In detecting non-conformities, there is an input that we want to add to make the system more efficient. The evaluator tests the "Halal Resto" Menu to find halal restaurants. The system displays a list of halal restaurants, certificate numbers, and valid dates on the start page. There are fields to search for restaurants. The evaluator tries to enter the certificate number in the column based on the name of the restaurant at the top displayed by the system (Figure 5). However, the results were not found. For input, It would be nice if the system could also receive input from the restaurant's halal certificate number, considering that the restaurant's name might not be known or written in foreign writing, for example, hangeul in Korean restaurants. Based on the assessment of the 8 points that have been presented, the severity rating of the three evaluators is as described in Table 3.

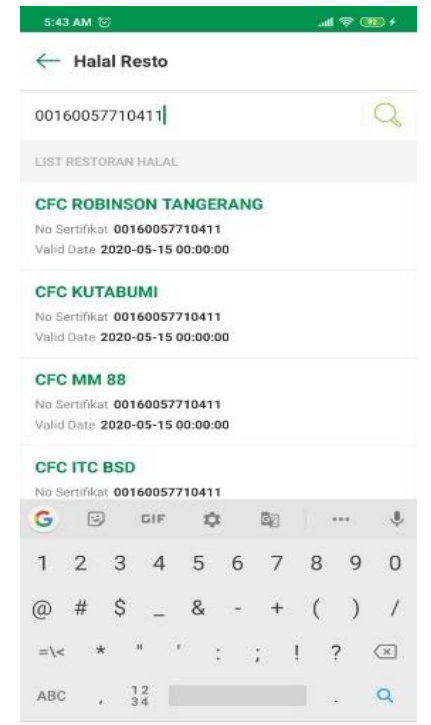

(a)

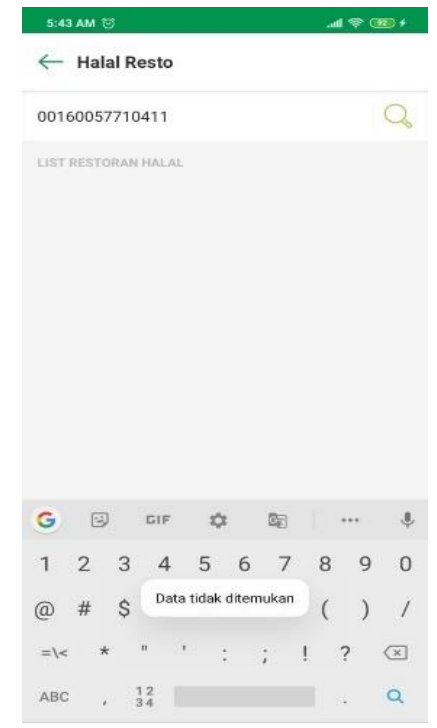

(b)

Figure 5. (a) Searching by Restaurant sertificate number, (b) Result display by the system

Table 3. Severity rating test result

\begin{tabular}{ccccc}
\hline Heuristic No & 1st evaluator & 2nd evaluator & 3rd evaluator & Total \\
\hline H1 & 1 & 1 & 1 & 3 \\
H2 & 1 & 0 & 0 & 1 \\
H3 & 1 & 2 & 1 & 4 \\
H4 & 0 & 0 & 0 & 0 \\
H5 & 0 & 0 & 0 & 0 \\
H6 & 4 & 4 & 4 & $\mathbf{1 2}$ \\
H7 & 2 & 2 & 2 & 6 \\
H8 & 2 & 4 & 3 & 9 \\
\hline
\end{tabular}

Heuristic test results show that there are several aspects included in the High priority issues, namely: H6 (1. Flexibility, the efficiency of use, and personalization) in the halal product scan context, and H8 (Realistic error management) regarding the search for Halal Restaurants. Medium priority issues are at 2 points, namely: H7 (Aesthetic, privacy, and social) and H3 (consistency and mapping) while low priority mapping is in 2 categories: H1 (Visibility of system status and loss/findability of the mobile device), and H2 (Match between system and the real world.

\section{CONCLUSION}

The heuristic evaluation has been carried out on the Halal MUI application. Based on research that has been done, we found several things that become high priority issues, which are precisely the main features of this application, namely: scan halal products and halal restaurants. The evaluator assessed that these two menus needed to be immediately improved to get the effectiveness of using a better system. 


\section{REFERENCES}

[1] Globalreligiousfuture, "Berapa Jumlah Penduduk Muslim Indonesia? (What is the Number of Indonesian Muslim Population?)," Katadata.Co.Id, 2019.

[2] Globalreligiousfutures, Indonesia, Negara dengan Penduduk Muslim Terbesar Dunia. p. 1, 20182018.

[3] A. mohd yunus, W. Wan Chik, and M. Mohamad, "The Concept of Halalan Tayyiba and Its Application in Products Marketing: A Case Study at Sabasun HyperRuncit Kuala Terengganu, Malaysia," Int. J. Bus. Soc. Sci., vol. 1, pp. 239-248, Dec. 2010.

[4] F. Armanios and B. A. Ergene, Halal food: a history. Oxford University Press, 2018.

[5] M. Tambrin, "Implementasi Undang-Undang Nomor 33 Tahun 2014 Tentang Jaminan Produk Halal (Implementation of Law Number 33 Year 2014 Regarding Halal Product Guarantee)," Direktur Urusan Agama Islam dan Pembin. Syariah Ditjen Bimas Islam, pp. 1-27, 2014.

[6] U. Islam and N. Syarif, "Survei 'Confidence Level' Konsumen Terhadap Produk Halal di Jakarta (Consumer Confidence Level Survey of Halal Products in Jakarta)."

[7] Majelis Ulama Indonesia, "Sejarah Majelis Ulama INdonesia (history of Majelis Ulama Indonesia)," p. 2020, 2019.

[8] LPPOM MUI, "Halal MUI - Aplikasi di Google Play." [Online]. Available: https://play.google.com/store/apps/details?id=com.lppommui.halalmui\&hl=en. [Accessed: 13-Dec-2019].

[9] U. Experience, U. Consultant, and E. Limited, Praise for Usability Testing Essentials. 2011.

[10] J. Nielsen, "How to Conduct a Heuristic Evaluation," Useitcom, pp. 1-11, 2002.

[11] A. G. Safitri, A. S. Prihatmanto, and P. H. Rusmin, "Design and implementation of educational game based on thematic curriculum using three layered thinking model (Case study: Applying number and social arithmetic in the real life)," in 2015 4th International Conference on Interactive Digital Media (ICIDM), 2015, pp. 1-7.

[12] Saifulloh and N. Asnawi, "Evaluasi Desain Antarmuka dengan Pendekatan Kemudahan Pengguna (Evaluate Interface Design with User Ease Approach)," J. Ilm. DASI, vol. 16, no. 1, pp. 96-100, 2015.

[13] R. Firmansyah, "Evaluasi Heuristik Pada Desain Interface Aplikasi My Indihome (Heuristic Evaluation of My Indihome Application Interface Design)," Semin. Nas. Ilmu Pengetah. dan Teknol. Komput., pp. 69-INF.76, 2016.

[14] D. R. Anggitama, H. Tolle, and H. M. Az-zahra, "Evaluasi Dan Perancangan User Interface Untuk Meningkatkan User Experience Menggunakan Metode Human Centered Design Dan Heuristic Evaluation Pada Aplikasi EzyPay (Evaluation and Design of User Interface to Improve User Experience Using Human Centered Desi," J. Pengemb. Teknol. Inf. dan Ilmu Komput. Univ. Brawijaya, vol. 2, no. 12, pp. 6152-6159, 2018.

[15] A. Baladina, I. Aknuranda, and A. Kusyanti, “Analisis Hasil Perbandingan Penerapan Metode Heuristic Evaluation Menggunakan Persona dan Tanpa Persona (Studi Kasus : Situs Web Female Daily) Comparative Analysis of the Application of the Heuristic Evaluation Method Using Persona and Without Persona (Ca," J. Pengemb. Teknol. Inf. dan Ilmu Komput. Univ. Brawijaya, vol. 2, no. 12, pp. 7050-7057, 2018.

[16] S. L. Nuryanti, "Pengukuran Usability Website dengan Metode Heuristic Evaluation (Studi Kasus: Website Penjualan PT Yudhistira Ghalia Indonesia) (Usability Measurement Website with Heuristic Evaluation Method (Case Study: PT Yudhistira Ghalia Indonesia's Sales Website)), $p$. http://repository.unpas.ac.id/40431/1/Siti\%20Latif, 2018.

[17] E. Paulus, M. Suryani, R. Farabi, I. N. Yulita, and A. Pradana, "Evaluasi Aplikasi Semi-Immersive Virtual Reality Pada Bidang Pendidikan Menurut Aspek Heuristik dan Pembelajaran (Evaluation of Semi-Immersive Virtual Reality Applications in Education According to Heuristic and Learning Aspects)," JIKO (Jurnal Inform. dan Komputer), vol. 1, no. 2, 2016.

[18] P. Prihati, M. Mustafid, and S. Suhartono, "Penerapan Model Human Computer Interaction (HCI) Dalam Analisis Sistem Informasi (Human Computer Interaction Application Model (HCI) in Information Systems Analysis)," J. Sist. Inf. BISNIS, vol. 1, no. 1, 2011.

[19] J. Nielsen, "Heuristic Evaluation: How-To: Article by Jakob Nielsen," Nielson Norman GroupNorman, no. Nielsen 1992, pp. 1-11, 1995.

[20] J. Nielsen, "How to Conduct Heuristic Evaluation," p. 59, 2007.

[21] J. Nielsen, "Finding usability problems through heuristic evaluation," Conf. Hum. Factors Comput. Syst. - Proc., pp. 373-380, 1992.

[22] J. Nielsen, "Severity Ratings for Usability Problems." [Online]. Available: https://www.nngroup.com/articles/howto-rate-the-severity-of-usability-problems/. [Accessed: 13-Dec-2019].

[23] J. Nielsen, "10 Heuristics for User Interface Design.” [Online]. Available: https://www.nngroup.com/articles/tenusability-heuristics/. [Accessed: 12-Dec-2019].

[24] J. Nielsen, "Usability Problems Found by Heuristic Evaluation," Nielsen Norman Group, 1995. [Online]. Available: https://www.nngroup.com/articles/usability-problems-found-by-heuristic-evaluation/. [Accessed: 12-Dec-2019].

[25] J. Nielsen, "Why You Only Need to Test with 5 Users," Jakob Nielsens Alertbox, 2000. [Online]. Available: http://www.useit.com/alertbox/20000319.html. [Accessed: 12-Dec-2019].

[26] J. Lumsden, Handbook of research on user interface design and evaluation for mobile technology, vol. 45, no. 12.2008 